\title{
Review Article \\ Coronaviruses in animals and humans, COVID-19 pandemic and one health approach
}

\author{
Mahesh $\mathrm{KC}^{1,4}$, Shristi Ghimire ${ }^{2,5}$, Namita Bhattarai ${ }^{3,6}$, and Santosh Dhakal ${ }^{2,7^{*}}$ \\ ${ }^{1}$ Center for Vaccines and Immunity, Nationwide Children's Hospital, Ohio, USA \\ ${ }^{2}$ Department of Molecular Microbiology and Immunology, Johns Hopkins Bloomberg, School of Public Health, Maryland, USA \\ ${ }^{3}$ Biotechnology Division, Nepal Agriculture Research Council (NARC), Khumaltar, Lalitpur, Nepal \\ ${ }^{4}$ ORCID ID: 0000-0002-5177-9566 \\ ${ }^{5}$ ORCID ID: 0000-0002-8121-9068 \\ ${ }^{6}$ ORCID ID: 0000-0001-7190-2114 \\ ${ }^{7}$ ORCID ID: 0000-0002-4494-8608
}

Received: May 23, 2020; Accepted: June 14, 2020; Published: June 25, 2020

\begin{abstract}
Coronaviruses can infect several animal species including cattle, pigs, dogs, and cats resulting in diseases related to respiratory and gastrointestinal systems. In humans, coronaviruses generally cause mild to moderate illnesses of the respiratory tract. Severe Acute Respiratory Syndrome Coronavirus (SARS-CoV) and Middle East Respiratory Syndrome Coronavirus (MERS-CoV), which emerged during 2002/03 and 2012/13 respectively, caused severe respiratory illnesses in humans. In December 2019, a novel respiratory coronavirus, SARS coronavirus 2 (SARS-CoV-2) emerged from Wuhan, China and caused coronavirus disease 2019 (COVID-19). Owing to the rapid spread of this virus, World Health Organization (WHO) declared COVID-19 outbreak as a global pandemic, which claimed over 300,000 lives by $16^{\text {th }}$ May 2020. Data available so far indicate that COVID-19-associated severe illnesses, hospitalizations and deaths are more common in elderly above 65 years of age; in men; and in individuals with underlying health conditions such as cardiovascular disease, hypertension and diabetes. SARS-CoV-2 is considered to be emerged from bats and likely involved certain, yet to be identified, intermediate animal host. Prevention and control of ongoing COVID-19 pandemic and possible disease outbreaks in the future by other emerging and reemerging pathogens, requires efficient implementation of one health strategy that utilizes the expertise of human, animal and environmental health sectors.
\end{abstract}

Keywords: Coronavirus, COVID-19, One Health, Pandemic, SARS-CoV-2

सारांश: कोरोना भाइरसले गाईवस्तु, सुँगुर, कुकुर र बिरालाहरू लगायतका धैरै जनावरका प्रजातिहरूलाई संक्रमित गर्न सक्छ र श्वासप्रश्वास तथा पाचन प्रणालीमा सम्बन्धित रोगहरू लगाउछ। मानवमा कोरोना भाइरसले सामान्यतया श्वासप्रश्वास प्रणालीमा हल्कादेखि मध्यम रोग निम्त्याउँछ। सन् २००२/०३ र सन् २०९२/१३ मा क्रमस सार्स र मर्स नाम गरेका कोरोना भाइरसहरु देखापरे जसले मान्छेमा श्वासप्रश्वासको गम्भीर रोगहरू निम्त्यायो। डिसेम्बर २०९९ मा, सार्स कोरोना भाइरस २ नाम गरेको नया कोरोना भाइरस चीनको वुहानमा देखा पन्यो जसले कोविड-१९ नाम गरेको गम्भीर रोग लगायो। यस भाइरसको तीव्र प्रसारको कारण, विश्व स्वास्थ्य संगठनले कोभिड-१९ लाइ विश्वव्यापी महामारीको रूपमा घोषित गज्यो। सन् २०२० मे १६ सम्म कोभिड-१९ ले विश्वभर ३००,००० भन्दा बढीको ज्यान लिइसकेको छ। अहिलेसम्म उपलब्ध तथ्यांक अनुसार कोभिड-१९ संग सम्बन्धित अस्पताल भर्ना र मृत्यु ६५ वर्षमाथिका वृद्धहरुमा, पुरुषहरुमा, र हृदय रोग, उच्च रक्तचाप तथा मधुमेह जस्ता रोगका विरामीहरुमा बढी देखिएको छ। सार्स कोरोना भाइरस २ को उत्पति चमेराबाट भएको मानिएपनि मान्छेमा सर्नुअघि यो भाइरसले कुन जनावरको सहारा लियो त्यो पत्ता लागिसकेको छैन। अहिले संसारभर फैलिरहेको कोभिड-१९ तथा भविष्यमा फैलन सक्ने यस्तै महामारीहरुको उचित रोकथाम र नियन्त्रणको लागि एक स्वास्थ्य रणनीतिको कुशल कार्यान्वयन आवश्यक छ जसले मानव, पशु र वातावरणीय स्वास्थ्य क्षेत्रहरूको विशेषज्ञताको समुचित प्रयोग गर्दछ।

\footnotetext{
* Corresponding authors, E-mail: sdhakal3@jhmi.edu; Tel.: +1 410-614-7794

(C) RECAST/TU
} 


\section{Introduction}

Coronaviruses are positive-sense, single-stranded RNA, and enveloped viruses belonging to the order Nidovirales, family Coronaviridae and subfamily Coronavirinae (Fehr \& Perlman, 2015). They have RNA genome of $26-30 \mathrm{~kb}$ size, one of the largest among the RNA viruses. Coronaviruses are classified further into four genera: alpha, beta, gamma, and delta coronaviruses. They have four types of structural proteins: spike, membrane, envelope, and nucleocapsid proteins, but additional hemagglutinin-esterase protein is also present in beta coronaviruses. Spike protein is responsible for attachment of the virion to the host cell (Gallagher \& Buchmeier, 2001). These viruses use different cellular receptors, such as human aminopeptidase $\mathrm{N}$ (CD13), angiotensin converting enzyme 2 (ACE2), 9-O-acetylated sialic acid, and dipeptidyl peptidase 4 for attachment and cell entry (Lim et al., 2016). These receptors are regarded as the determinants of host range, tissue tropism, and pathogenicity.
Coronaviruses infect both humans and animals.

Those infecting humans are mostly clustered in alpha and beta coronaviruses whereas viruses infecting animals fall in all four genera. Human coronaviruses typically cause respiratory tract illnesses including common cold, cough, pneumonia, and bronchitis (Pene et al., 2003; Lim et al., 2016). Coronaviruses can infect several animal species including cattle, pigs, dogs, cats, and poultry resulting in diseases related to respiratory and gastrointestinal system (Saif, 2004; Fehr \& Perlman, 2015). Bats are considered as a reservoir host for many coronaviruses, while zoonotic transmission to humans is possible through intermediate animal hosts (Su et al., 2016; Li et al., 2020). The current pandemic of coronavirus disease 2019 (COVID-19) is caused by a Severe Acute Respiratory Syndrome Coronavirus 2 (SARS-CoV-2). In this review, we have summarized different coronaviruses infecting animals and humans; status of COVID-19 pandemic; and the importance of one health approach to deal with outbreaks like COVID-19.

Table 1. Summary of coronavirus infection in different animal species

\begin{tabular}{|c|c|c|c|}
\hline Species & Virus & Genus & System affected \\
\hline \multirow{2}{*}{ Pig } & $\begin{array}{c}\text { Transmissible gastroenteritis virus } \\
\text { (TGEV) }\end{array}$ & Alpha coronavirus & Gastrointestinal \\
\cline { 2 - 4 } & $\begin{array}{c}\text { Porcine epidemic diarrhea virus } \\
(\text { PEDV) }\end{array}$ & Alpha coronavirus & Gastrointestinal \\
\cline { 2 - 4 } & Porcine delta coronavirus (PdCV) & Delta coronavirus & Gastrointestinal \\
\cline { 2 - 4 } & Porcine respiratory coronavirus \\
(PRCV) & Alpha coronavirus & Respiratory \\
\hline Cattle & Bovine coronavirus & Beta coronavirus & $\begin{array}{c}\text { Both gastrointestinal and } \\
\text { respiratory }\end{array}$ \\
\hline Chicken & Infectious bronchitis virus & Gamma coronavirus & Respiratory \\
\hline Turkey & Turkey coronavirus & Gamma coronavirus & Gastrointestinal \\
\hline Dog & Canine coronavirus & Alpha coronavirus & Gastrointestinal \\
\hline \multirow{2}{*}{ Cat } & Canine respiratory coronavirus & Beta coronavirus & Respiratory \\
\hline
\end{tabular}

\section{Coronaviruses in Animals}

Historically, coronaviruses were first identified in the chickens in 1930s in the form of infectious bronchitis (IB) virus (Beach \& Schalm, 1936; Estola, 1970). Since then, many coronaviruses and associated diseases are reported in livestock and pet animals (Table 1). For example, bovine respiratory coronavirus (BCoV) causes mild to severe respiratory tract and enteric infection in cattle (Saif, 2010; Amer, 2018). Interspecies transmission of
$\mathrm{BCoVs}$ can occur between ruminants like camels, elk, deer, and water buffalo (Amer, 2018). Similarly, Transmissible Gastroenteritis Virus (TGEV) and Porcine Epidemic Diarrhea Virus (PEDV) are the alpha coronaviruses that cause severe gastroenteritis in piglets less than 2 weeks of age with almost $100 \%$ mortality (Laude et al., 1990; Jung \& Saif, 2015). In pigs, porcine delta coronavirus is also responsible for acute diarrhea, vomiting, and mortality in neonatal pigs (Jung et al., 2016). The emergence of highly 
virulent PEDV strain in the United States (US) in 2013, resulted in the death of around 8 million pigs leading to huge economic losses in the US swine industry (Stevenson et al., 2013). Coronaviruses have been associated with infection in pet animals as well. Canine coronaviruses cause both gastrointestinal and respiratory disease in dogs which are usually mild with severe infection in some instances (Buonavoglia et al., 2006). Coronavirus infection is also common in cat resulting in feline infectious peritonitis (Hartmann, 2005). Coronavirus infection in animals is widespread globally however, there are not many reports available on the status of coronavirus-related diseases among animals in Nepal. At least, some information is available related to avian coronavirus i.e., avian infectious bronchitis virus (IBV) infection in Nepal (Gompo et al., 2019; Office International des Epizooties [OIE], 2019a). According to an epidemiological study conducted by Gompo et al. (2019), infectious bronchitis is among the top 10 poultry diseases in Nepal and the existence of the disease in avian species is also supported by reports submitted to OIE.

\section{Coronaviruses in Humans}

The first human coronavirus ( $\mathrm{HCoV}), \mathrm{B} 814$ virus, was discovered in 1960s (Tyrrell \& Bynoe, 1966; Kahn \& McIntosh, 2005). This virus was isolated from the nasal wash of the individual who developed cold. Since then the other $\mathrm{HCoVs}$, namely $\mathrm{HCoV}$ 229E, HCoV-NL63, HCoV-OC43, and HCoVHKU1 are known to cause a significant fraction of common cold infections globally with mild to moderate diseases ( $\mathrm{Su}$ et al., 2016). HCoV-229E, HCoV-NL63 belong to genera alpha coronavirus while HCoV-OC43 and HCoV-KHU1 belong to genera beta coronavirus. These virus infections are most common during the winter season (Gaunt et al., 2010; Uddin et al., 2018). One study conducted among infants in Nepal, between 2011-2013, showed $8 \%$ prevalence of HCoVs (Uddin et al., 2018). The four $\mathrm{HCoVs}$ were found to be in the infections with the highest prevalence of HCoV-OC43 followed by HKU1, NL63, and 229E in Nepal. Diseases related to human coronaviruses were considered mild before the outbreak of severely pathogenic severe acute respiratory syndrome coronavirus (SARS-CoV). The SARS outbreak which occurred in 2002/03 resulted in over 8000 cases and 774 deaths in 27 countries (de Wit et al., 2016). After a decade, Middle East Respiratory Syndrome Coronavirus (MERS-CoV) emerged. By 2019, there were 2494 confirmed cases and over 858 deaths were reported due to MERS in 27 countries (World Health Organization [WHO], 2020a). SARS-CoV was originated from bat, and palm civet is regarded as the intermediate animal host (Wang et al., 2005; Hu et al., 2015). Likewise, for MERS, bats are the reservoir host and camels are regarded as intermediate animal host (Omrani et al., 2016). No cases of SARS and MERS were ever reported in Nepal (WHO, 2020a, 2020b). Even within less than a decade of the occurrence of MERS outbreak, another coronavirus named SARS coronavirus 2 (SARS-CoV-2) emerged that is causing the COVID-19 pandemic.

\section{COVID-19 Pandemic}

A novel coronavirus causing severe respiratory illness in people was first reported in December 2019 from Wuhan, China. This novel coronavirus had nearly $90 \%$ nucleotide sequence similarity to batorigin SARS-like coronaviruses and caused disease similar to earlier SARS-CoV infection in humans (Wu et al., 2020). World Health Organization (WHO) later named the virus as SARS coronavirus 2 (SARS-CoV-2) and the disease as COVID-19 (WHO, 2020b). Owing to the rapid spread of this virus worldwide, WHO declared outbreak of COVID-19 as a pandemic on March 11, 2020 (WHO, 2020b). It is likely that SARS-CoV-2 originated from bats but the information about the intermediate animal hosts involved is not available yet (Lau et al., 2020).

SARS-CoV-2 is primarily transmitted through respiratory droplets and contact with the infected people (Liu et al., 2020). Transmission may also occur through contact with contaminated fomites around the infected person (Ong et al., 2020). People infected with SARS-CoV-2 show a wide range of symptoms that range from mild to severe illnesses. The common symptoms include fever, cough, shortness of breath, headache, fatigue and muscle pain. Symptoms may develop in 2 to 14 days in the infected individuals (Centers for Disease Control and Prevention [CDC], 2020a). Most people infected with SARS-CoV-2 remain asymptomatic that could be the major reason behind rapid transmission of COVID-19 (Furukawa et al., 2020).

SARS-CoV-2 has been isolated from stool of infected person suggesting that fecal-oral transmission might be a possibility, but it needs further confirmation (WHO, 2020c; Zhang et al., 2020). Recently, multiorgan tropism of SARS-CoV2 , beyond the respiratory tract and including the kidneys, heart, liver, and brain, is also reported during autopsy of people who died with COVID-19 (Puelles et al., 2020).

As of 16th May 2020, SARS-CoV-2 has infected over 4.6 million people and claimed over 300,000 lives from 215 countries and territories in the world (Coronavirus Update Worldometer, 2020; WHO, 2020c). Host-associated factors including biological 
sex (being man or woman) and age (being a child or reproductive age adult or elderly) can play a significant role in the outcome of infection or immunity development (Dhakal \& Klein, 2019). During COVID-19 pandemic, severe illnesses, hospitalizations, and deaths are mostly observed in elderly above 65 years of age (CDC, 2020a). Likewise, most of the countries that segregated data by biological sex (being a man or woman) have shown that death rate due to COVID-19 is greater in men than in women (Klein et al., 2020). Similarly, underlying medical conditions such as chronic respiratory disease, cardiovascular disease, cancer, diabetes, and hypertension are mostly associated with a higher severity of the disease and deaths (Jordan et al., 2020; Wu et al., 2020).

\section{COVID-19 Prevention and Control Strategies}

Isolation of SARS-CoV-2 infected or suspected people and restriction in their movement is highly recommended by WHO and Centers for Disease Control and Prevention (CDC) of USA in case of COVID-19 disease (WHO, 2020d; CDC, 2020b). Maintaining personal hygiene through regular handwash with soap water for at least 20 seconds and use of hand sanitizer can limit the spread of the virus infection. Additionally, other hygienic habits like avoiding touching mouth, nose, and eye with hands should be considered. Wearing nonsurgical and cloth masks for general public and N95 masks for health professionals working closely with infected or suspected people are also regarded as the best practices to prevent spread of droplets from the infected to the susceptible persons (Food and Drug Administration [FDA], 2020b).

In addition to personal hygiene, nonpharmaceutical interventions like social distancing and staying at home are also recommended and enforced in many countries (WHO, 2020c; CDC, 2020b). The effective use of the personal hygiene and nonpharmaceutical interventions combined with massive testing were helpful in getting control over COVID-19 outbreak in China and hence almost all other countries are also following the similar strategies to control the SARS-CoV-2 transmission (Adhikari et al., 2020). As of now, there is no approved treatment available for COVID-19 but several research trials at different levels using different drugs are ongoing. There are reports that drugs including remdesivir, hydoroxychloroquine, azithromycin etc. could be effective to treat COVID19 (Gautret et al., 2020; Manli Wang et al., 2020). On May $1^{\text {st }}, 2020$, the US Food and Drug Administration (FDA) provided 'emergency use authorization' to the drug remdesivir owing to its observed benefits in animal and human studies
(FDA, 2020a). In addition to the therapeutic treatments, tremendous efforts have been applied by scientists all over the world to develop vaccines against the SARS-CoV-2 infection. So far, more than 115 vaccine candidates have been developed and are in either preclinical or early stages of clinical trials (Le et al., 2020). Under normal circumstances, development of vaccines takes years. However, owing to the devotion of each and every scientific body throughout the globe; and investment and supports from the private and public resources; it is likely that vaccine against COVID-19 will be developed in 12 to 18 month period (Amanat \& Krammer, 2020).

\section{One Health Approach and COVID-19 Pandemic}

One health is a public health strategy to combine the efforts of multisectoral professions including human health, animal health, and environmental health to tackle the emerging and re-emerging pathogens and achieve better public health outcomes (Kelly et al., 2017; Lebov et al., 2017). About 75\% of the human infectious diseases have animal origin and $60 \%$ are zoonotic. This highlights the importance of professionals working in both animal and public health to join hands together to address the heath issues at human and animal interface (OIE, $2019 b)$. One health approach is important to address several global health issues including antimicrobial resistance and control of zoonoses (McEwen \& Collignon, 2018). Prevention of zoonotic disease is only possible through coordinated efforts among veterinary and public health sectors. For example, rabies in humans can only be prevented by getting control over the animal source of the virus. Similarly, control of influenza viruses in human is only possible through control in animals to prevent the emergence of new strains and subtypes (Capua \& Cattoli, 2010).

One health approach helps to identify the source of infection and track the pathogen transmission pattern which is critical to reduce the challenges of emerging and reemerging viruses (Kelly et al., 2017; Lebov et al., 2017). SARS-CoV-2 emerged from its ancestral bat host and it is likely that certain intermediate animal host was involved before its spillover to humans (Zhou et al., 2020). In the context of unknown intermediate host, one health approach can be helpful to understand the SARSCoV-2 transmission from bat to humans. Early studies have shown that SARS-CoV-2 can infect dogs, cats, and tigers, though their roles in virus transmission to humans is not yet confirmed (American Veterinary Medical Association [AVMA], 2020). Determination of the intermediate host for SARS-CoV-2 transmission will help to 
investigate further on host-pathogen interaction and design effective plans to prevent the virus transmission (El Zowalaty \& Järhult, 2020). The ongoing COVID-19 pandemic has once again highlighted the importance of research at humanenvironment-animal interface to ensure the timely and efficient response against such outbreaks even in the future (Amuasi et al., 2020).

Lately, the importance of one health approach has been realized in Nepal as well, but there is a long way to go before its proper implementation. The veterinary professionals in Nepal have been dealing with avian influenza virus and other outbreaks for a long time resulting in the development of better research and diagnostic expertise and facilities. In the ongoing COVID-19 pandemic, multiple veterinary laboratory facilities and resources are being utilized for the disease diagnosis in Nepal. This fact emphasizes the necessity of continued collaboration between human health sector, animal health sector, microbiologists, public health experts, and other stakeholders in the future to prevent and control any such outbreaks as COVID-19.

\section{Conclusion}

COVID-19 pandemic already infected millions of people and killed thousands all over the world. In the absence of approved therapeutics and vaccines, it will continuously affect a larger population in coming days leading to more cases and deaths. Despite the ongoing nonpharmaceutical mitigation efforts and apparent elimination, the detrimental effect of SARS-CoV-2 is expected to persist longer (Kissler et al., 2020). Scientists are thinking that this virus may never disappear and keep circulating as influenza viruses. Thus, there is urgent need of development of vaccines and drugs to deal with COVID-19. Moreover, the world is facing pandemics regularly at the interval of 10-50 years. Owing to the emergence and re-emergence of several zoonotic viruses, it can be predicted that another pandemic is also inevitable in the future. Proper implementation of one health approach that brings environmental, animal, and human health experts together will thus be vital for better preparedness against future disease outbreaks.

Authors Contribution: SD conceived the idea; MKC, SG, NB and SD wrote and revised the manuscript. All authors have read and approved final version of the manuscript.

Conflicts of Interest: The authors declare no conflicts of interest.
Funding: No funding was sought or obtained to conduct this study.

\section{Ethical approval}

Not required given the nature of the article.

\section{References}

Adhikari SP, Meng S, Wu Y-J, Mao Y-P, Ye R-X, Wang Q-Z, et al. Epidemiology, causes, clinical manifestation and diagnosis, prevention and control of coronavirus disease (COVID-19) during the early outbreak period: a scoping review. Infect Dis Poverty. 2020 Mar 17;9(1):29. https://doi.org/10.1186/s40249-020-00646-X

Amanat F, Krammer F. SARS-CoV-2 Vaccines: Status report. Immunity. 2020 Apr 6; Available from: https://www.ncbi.nlm.nih.gov/pmc/articles/PMC7136867/. https://doi.org/10.1016/j.immuni.2020.03.007

Amer HM. Bovine-like coronaviruses in domestic and wild ruminants. Anim Health Res Rev. 2018;19(2):113-24. https://doi.org/10.1017/S1466252318000117

American Veterinary Medical Association. SARS-CoV-2 in animals. 2020 [Cited May 15 2020] Available from: https://www.avma.org/resources-tools/animal-health-andwelfare/covid-19/sars-cov-2-animals-including-pets

Amuasi JH, Walzer C, Heymann D, Carabin H, Huong LT, Haines A, et al. Calling for a COVID-19 One health research coalition. The Lancet. 2020 May 16;395(10236):1543-4. https://doi.org/10.1016/S01406736(20)31028-X3

Beach JR, Schalm OW. A filterable virus, distinct from that of Laryngotracheitis, the cause of a respiratory disease of chicks. Poult Sci. 1936 May 1;15(3):199-206. https://doi.org/10.3382/ps.0150199

Buonavoglia C, Decaro N, Martella V, Elia G, Campolo M, Desario C, et al. Canine coronavirus highly pathogenic for dogs. Emerg Infect Dis. 2006 Mar;12(3):492-4. https://doi.org/10.3201/eid1203.050839

Capua I, Cattoli G. One flu for one health. Emerg Infect Dis. $2010 \quad$ Apr;16(4):719. https://doi.org/10.3201/eid1604.091593

Centers for Disease Control and Prevention. Coronavirus Disease 2019 (COVID-19) - Symptoms. 2020a [Cited May 15, 2020]. Available from: https://www.cdc.gov/coronavirus/2019-ncov/symptomstesting/symptoms.html

Centers for Disease Control and Prevention. Coronavirus Disease 2019 (COVID-19) - Prevention \& Treatment. 2020b [Cited May 15, 2020]. Available from: https://www.cdc.gov/coronavirus/2019-ncov/prevent-gettingsick/prevention.html

Coronavirus Update (Live): 4,666,736 Cases and 309,864 Deaths from COVID-19 virus pandemic - Worldometer. 2020 [Cited May 15, 2020]. Available from: https://www.worldometers.info/coronavirus/

de Wit E, van Doremalen N, Falzarano D, Munster VJ. SARS and MERS: recent insights into emerging coronaviruses. Nat Rev Microbiol. 2016 Aug;14(8):523-34. https://doi.org/10.1038/nrmicro.2016.81

Dhakal S, Klein SL. Host factors impact vaccine efficacy: Implications for seasonal and universal influenza vaccine programs. J Virol. https://doi.org/10.1128/JVI.00797-19

El Zowalaty ME, Järhult JD. From SARS to COVID-19: A previously unknown SARS- related coronavirus (SARS- 
CoV-2) of pandemic potential infecting humans - Call for a One Health approach. One Health Amst Neth. 2020 Jun; 9:100124. https://doi.org/10.1016/j.onehlt.2020.100124

Estola T. Coronaviruses, a new group of animal RNA viruses. Avian Dis. 1970;14(2):330-6. https://doi.org/10.2307/1588476

Fehr, AR, Perlman S. Coronaviruses: An overview of their replication and pathogenesis. Methods in Molecular Biology (2015), 1282, 1-23. https://doi.org/10.1007/978-14939-2438-7 1

Food and Drug Administration. Coronavirus (COVID-19) Update: FDA issues emergency use authorization for potential COVID-19 treatment. 2020a [Cited May 13, 2020]. Available from: https://www.fda.gov/news-events/pressannouncements/coronavirus-covid-19-update-fda-issuesemergency-use-authorization-potential-covid-19-treatment

Food and Drug Administration. N95 respirators and surgical masks (Face Masks). 2020b Apr 5; [Cited May 13, 2020] Available from: https://www.fda.gov/medicaldevices/personal-protective-equipment-infection-control/n95respirators-and-surgical-masks-face-masks

Furukawa NW, Brooks JT, Sobel J. Early Release Evidence supporting transmission of severe acute respiratory syndrome coronavirus 2 while presymptomatic or asymptomatic - Volume 26, Number 7-July 2020 - Emerging Infectious Diseases journal - CDC; Available from: https://wwwnc.cdc.gov/eid/article/26/7/20-1595_article. https://doi.org/10.3201/eid2607.201595

Gallagher TM, Buchmeier MJ. Coronavirus spike proteins in viral entry and pathogenesis. Virology. 2001 Jan 20;279(2):371-4. https://doi.org/10.1006/viro.2000.0757

Gaunt ER, Hardie A, Claas ECJ, Simmonds P, Templeton KE. Epidemiology and clinical presentations of the four human coronaviruses 229E, HKU1, NL63, and OC43 detected over 3 years using a novel multiplex real-time PCR method. J Clin Microbiol. 2010 Aug;48(8):2940-7. https://doi.org/10.1128/JCM.00636-10

Gautret P, Lagier J-C, Parola P, Hoang VT, Meddeb L, Mailhe $\mathrm{M}$, et al. Hydroxychloroquine and azithromycin as a treatment of COVID-19: results of an open-label nonrandomized clinical trial. Int J Antimicrob Agents. 2020 Mar 20;105949.https://doi.org/10.1016/j.ijantimicag.2020.105949

Gompo TR, Pokhrel U, Shah BR, Bhatta DD Epidemiology of important poultry diseases in Nepal. Nepal $\begin{array}{lllll}\text { Vet } & \text { J. } & 2019 & \text { Dec } & 1 ; 36: 8-14 .\end{array}$ https://doi.org/10.3126/nvj.v36i0.27746

Hartmann K. Feline infectious peritonitis. Vet Clin Small Anim Pract. 2005 Jan 1;35(1):39-79. https://doi.org/10.1016/j.cvsm.2004.10.011

$\mathrm{Hu}$ B, Ge X, Wang L-F, Shi Z. Bat origin of human coronaviruses. Virol J. 2015 Dec;12(1):221. https://doi.org/10.1186/s12985-015-0422-1

Jordan RE, Adab P, Cheng KK. Covid-19: Risk factors for severe disease and death. BMJ. 2020 Mar 26 ;368. Available

https://www.bmj.com/content/368/bmj.m1198. https://doi.org/10.1136/bmj.m1198

Jung $\mathrm{K}, \mathrm{Hu} \mathrm{H}$, Saif LJ. Porcine deltacoronavirus infection: Etiology, cell culture for virus isolation and propagation, molecular epidemiology and pathogenesis. $\begin{array}{llll}\text { Virus } & \text { Res. } & 2016 \quad \text { Dec 2;26:50-9. }\end{array}$ https://doi.org/10.1016/j.virusres.2016.04.009

Kahn JS, McIntosh K. History and recent advances in coronavirus discovery. Pediatr Infect Dis J. 2005 Nov;24 (11 Suppl):S223-227, discussion

S226. https://doi.org/10.1097/01.inf.0000188166.17324.60

Kelly TR, Karesh WB, Johnson CK, Gilardi KVK, Anthony SJ, Goldstein T, et al. One Health proof of concept: Bringing a transdisciplinary approach to surveillance for zoonotic viruses at the human-wild animal interface. Prev $\begin{array}{lllll}\text { Vet } & \text { Med. } 2017 \text { Feb 1;137(Pt } & \text { B):112-8. }\end{array}$ https://doi.org/10.1016/j.prevetmed.2016.11.023

Kissler SM, Tedijanto C, Goldstein E, Grad YH, Lipsitch M. Projecting the transmission dynamics of SARS-CoV-2 through the postpandemic period. Science. 2020 Apr 14. https://doi.org/10.1126/science.abb5793

Klein SL, Dhakal S, Ursin RL, Deshpande S, Sandberg K, Mauvais-Jarvis F. Biological sex impacts COVID-19 outcomes. PLoS Pathog. 2020 Jun 22; 16(6);e1008570. http://doi.org/10.1371/journal.ppat.1008570

Lau SKP, Luk HKH, Wong ACP, Li KSM, Zhu L, He Z, et al. Early Release - Possible bat origin of severe acute respiratory syndrome coronavirus 2 - Volume 26, Number 7 July 2020 - Emerging Infectious Diseases journal - CDC. Available from: https://wwwnc.cdc.gov/eid/article/26/7/20 0092_article. https://doi.org/10.3201/eid2607.200092

Laude H, Rasschaert D, Delmas B, Godet M, Gelfi J, Charley B. Molecular biology of transmissible gastroenteritis virus. Vet Microbiol. 1990 Jun;23(1-4):147-54. https://doi.org/10.1016/0378-1135(90)90144-k

Le TT, Andreadakis Z, Kumar A, Román RG, Tollefsen S, Saville M, et al. The COVID-19 vaccine development landscape. Nat Rev Drug Discov. 2020 Apr 9;19(5):305-6. https://doi.org/10.1038/d41573-020-00073-5

Lebov J, Grieger K, Womack D, Zaccaro D, Whitehead N, Kowalcyk B, et al. A framework for One Health research. One Health. 2017 Jun 1;3:44-50. https://doi.org/10.1016/j.onehlt.2017.03.004

Li X, Song Y, Wong G, Cui J. Bat origin of a new human coronavirus: there and back again. Sci China Life Sci. 2020 Mar 1;63(3):461-2. https://doi.org/10.1007/s11427-020$1645-7$

Lim YX, Ng YL, Tam JP, Liu DX. Human Coronaviruses: A review of virus-host interactions. Diseases. $2016 \mathrm{Jul} 25$;4(3). https://doi.org/10.3390/diseases4030026

Liu J, Liao X, Qian S, Yuan J, Wang F, Liu Y, et al. Early Release - Community transmission of severe acute respiratory syndrome coronavirus 2, Shenzhen, China, 2020 Volume 26, Number 6-June 2020 - Emerging Infectious Diseases journal - CDC. Available from: https://wwwnc.cdc.gov/eid/article/26/6/20-0239_article.

https://doi.org/10.3201/eid2606.200239

McEwen SA, Collignon PJ. Antimicrobial Resistance: A one health perspective. Microbiol Spectr. 2018;6(2). https://doi.org/10.1128/microbiolspec.ARBA-0009-2017

Office International des Epizooties. World animal health information system. 2020a [Cited 2020 May 12]. Available from:

https://www.oie.int/wahis_2/public/wahid.php/Reviewreport/ semestrial/review ?year $=2019 \&$ semester $=1 \&$ wild $=0 \&$ country $=$ NPL\&this_country_code $=$ NPL\&detailed $=1$

Office International des Epizooties. OneHealth: OIE World organization for animal health. 2020b [Cited May 13, 2020]. Available from: https://www.oie.int/en/for-themedia/onehealth/

Omrani AS, Al-Tawfiq JA, Memish ZA. Middle east respiratory syndrome coronavirus (MERS-CoV): animal to human interaction. Pathog Glob Health. 2016 Feb 18;109(8):354-62.

https://doi.org/10.1080/20477724.2015.1122852 
Ong SWX, Tan YK, Chia PY, Lee TH, Ng OT, Wong MSY, et al. Air, surface environmental, and personal protective equipment contamination by severe acute respiratory syndrome coronavirus 2 (SARS-CoV-2) From a Symptomatic Patient. JAMA. 2020 Mar 4. https://doi.org/10.1001/jama.2020.3227

Pene F, Merlat A, Vabret A, Rozenberg F, Buzyn A, Dreyfus F, et al. Coronavirus 229E-related pneumonia in immunocompromised patients. Clin Infect Dis Off Publ Infect Dis Soc Am. 2003 Oct 1;37(7):929-32. https://doi.org/10.1086/377612

Puelles VG, Lütgehetmann M, Lindenmeyer MT, Sperhake JP, Wong MN, Allweiss L, et al. Multiorgan and renal tropism of SARS-CoV-2. N Engl J Med. 2020 May 13. https://doi.org/10.1056/NEJMc2011400

Saif, LJ. Animal coronaviruses: what can they teach us about the severe acute respiratory syndrome? 2004 Jan;23(2):643-60. http://dx.doi.org/10.20506/rst.23.2.1513

Saif LJ. Bovine respiratory coronavirus. Vet Clin North Am Food Anim Pract. 2010 Jul;26(2):349-64. https://doi.org/10.1016/j.cvfa.2010.04.005

Stevenson GW, Hoang H, Schwartz KJ, Burrough ER, Sun D, Madson D, et al. Emergence of porcine epidemic diarrhea virus in the United States: clinical signs, lesions, and viral genomic sequences. J Vet Diagn Investig Off Publ Am Assoc Vet Lab Diagn Inc. 2013 Sep;25(5):649-54 https://doi.org/10.1177/1040638713501675

Su S, Wong G, Shi W, Liu J, Lai ACK, Zhou J, et al. Epidemiology, genetic recombination, and pathogenesis of coronaviruses. Trends Microbiol. 2016 Jun;24(6):490-502. https://doi.org/10.1016/j.tim.2016.03.003

Tyrrell DA, Bynoe ML. Cultivation of viruses from a high proportion of patients with colds. Lancet Lond Engl. 1966 Jan 8;1(7428):76-7. https://doi.org/10.1016/s01406736(66)92364-6

Uddin SMI, Englund JA, Kuypers JY, Chu HY, Steinhoff MC, Khatry SK, et al. Burden and risk factors for coronavirus infections in infants in rural Nepal. Clin Infect Dis Off Publ Infect Dis Soc Am. 2018 Nov 15;67(10):150714. https://doi.org/10.1093/cid/ciy317

Wang M, Cao R, Zhang L, Yang X, Liu J, Xu M, et al. Remdesivir and chloroquine effectively inhibit the recently emerged novel coronavirus (2019-nCoV) in vitro. Cell Res. 2020 Mar;30(3):269-71. https://doi.org/10.1038/s41422-020 0282-0
Wang M, Yan M, Xu H, Liang W, Kan B, Zheng B, et al. SARS-CoV infection in a restaurant from palm civet. Emerg Infect Dis. 2005 Dec;11(12):1860-5. https://doi.org/10.3201/eid1112.041293

World Health Organization. Middle East Respiratory Syndrome Coronavirus (MERS-CoV). 2020a [Cited May 10, 2020]. Available from: http://www.who.int/emergencies/mers-cov/en/

World Health Organization. Severe Acute Respiratory Syndrome (SARS). 2020b [Cited May 10, 2020]. Available from: https://www.who.int/csr/sars/press/en/7

World Health Organization. Modes of transmission of virus causing COVID-19. Implications for IPC precaution recommendations. 2020c [Cited May 10, 2020]. Available from: https://www.who.int/newsroom/commentaries/detail/modes-of-transmission-of-viruscausing-covid-19-implications-for-ipc-precautionrecommendations

World Health Organization. Coronavirus disease (COVID-19) advice for the public. 2020d [Cited May 10, 2020]. Available from: https://www.who.int/emergencies/diseases/novelcoronavirus-2019/advice-for-public

Wu C, Chen X, Cai Y, Xia J, Zhou X, Xu S, et al. Risk factors associated with acute respiratory distress syndrome and death in patients with coronavirus disease 2019 pneumonia in Wuhan, China. JAMA Intern Med. 2020 Mar 13. https://doi.org/10.1001/jamainternmed.2020.0994

Wu F, Zhao S, Yu B, Chen Y-M, Wang W, Song Z-G, et al. A new coronavirus associated with human respiratory disease in China. Nature. 2020 Mar;579(7798):265-9. https://doi.org/10.1038/s41586-020-2008-3

Zhang Y, Chen C, Zhu S, Shu C, Wang D, Song J, et al. Isolation of 2019-ncov from a stool specimen of a laboratoryconfirmed case of the coronavirus disease 2019 (COVID-19). China CDC Wkly. 2020 Feb 1;2(8):123-4 https://doi.org/10.46234/ccdcw2020.033

Zhou P, Yang X-L, Wang X-G, Hu B, Zhang L, Zhang $\mathrm{W}$, et al. A pneumonia outbreak associated with a new coronavirus of probable bat origin. Nature. 2020 Mar;579(7798):270-3. https://doi.org/10.1038/s41586-0202012-7 